\title{
Electrochemical behavior of stainless steel alloys used for medical and dental applications as a function of exposure to $0.9 \% \mathrm{NaCl}$ and sterilization
}

\author{
Comportamento eletroquímico de ligas de aço inoxidável utilizadas para aplicações médicas e \\ dentárias em função da exposição a $0,9 \% \mathrm{NaCl}$ e esterilização \\ Comportamiento electroquímico de aleaciones de acero inoxidable utilizadas para aplicaciones \\ médicas y dentales en función de exposición a $0,9 \%$ NaCl y esterilización
}

Received: 03/04/2021 | Reviewed: 03/16/2021 | Accept: 04/23/2021 | Published: 05/09/2021

\author{
Cecília Alves de Sousa \\ ORCID: https://orcid.org/0000-0002-4192-5486 \\ São Paulo State University, Brazil \\ E-mail: ceciliasousa_alves@hotmail.com \\ Carolina Ferrairo Danieletto-Zanna \\ ORCID: https://orcid.org/0000-0003-1891-8250 \\ São Paulo University, Brazil \\ E-mail: carol_danieletto@hotmail.com \\ Thamara Beline \\ ORCID: https://orcid.org/0000-0002-9729-1160 \\ University of Campinas, Brazil \\ E-mail: thamara.beline@gmail.com \\ Gustavo Zanna Ferreira \\ ORCID: https://orcid.org/0000-0002-0063-9512 \\ São Paulo University, Brazil \\ E-mail: gustavozanna@hotmail.com \\ Leonardo Perez Faverani \\ ORCID: https://orcid.org/0000-0003-2249-3048 \\ São Paulo State University, Brazil \\ E-mail: leonardo.faverani@unesp.br \\ Valentim Adelino Ricardo Barão \\ ORCID: https://orcid.org/0000-0002-6391-9917 \\ University of Campinas, Brazil \\ E-mail: ricardo.barao@hotmail.com \\ Wirley Gonçalves Assunção \\ ORCID: https://orcid.org/0000-0002-8903-0737 \\ São Paulo State University, Brazil \\ E-mail: wirley.assuncao@unesp.br
}

\begin{abstract}
This study evaluated the effect of disinfection procedures and exposure to $0.9 \% \mathrm{NaCl}$ solution cycles during sterilization, on the electrochemical, physical and chemical properties of different stainless steel alloys used in the biomedical field. Discs of F899 XM16, F899 303, and F899 420B alloys were cleaned with enzymatic detergent followed by 20 cycles of autoclave sterilization. Electrochemical tests were performed including open circuit potential, electrochemical impedance spectroscopy, and potentiodynamic polarization tests in $0.9 \% \mathrm{NaCl}(\mathrm{n}=5)$. Surface characterization was performed using scanning electron microscopy (SEM), energy dispersive spectroscopy, and surface roughness and microhardness both before and after the electrochemical test. Quantitative data were analyzed with a significance level of 5\%. The corrosion current density and corrosion potential of the alloys did not present statistical differences. The capacitance values of the three oxide layers, polarization resistance, and impedance of Warburg were similar among the alloys. Considering the topography, surface roughness increased for all alloys in the post-corrosion period. The stainless steel alloys analyzed were negatively affected at the electrochemical behavior, corrosion kinetics, and surface characterization after the $0.9 \% \mathrm{NaCl}$ solution and the autoclave sterilization cycles, confirming the need for regular exchanges of surgical instruments and drills used in medical and dental implantology.

Keywords: Stainless steel; Alloys; Corrosion; Sodium chloride; Sterilization.
\end{abstract}

\section{Resumo}

Este estudo avaliou o efeito de procedimentos de desinfecção e exposição a ciclos de solução de $\mathrm{NaCl}$ a $0,9 \%$ durante a esterilização, nas propriedades eletroquímicas, físicas e químicas de diferentes ligas de aço inoxidável utilizadas na área biomédica. Os discos das ligas F899 XM16, F899 303 e F899 420B foram limpos com detergente enzimático seguido de 20 ciclos de esterilização em autoclave. Testes eletroquímicos foram realizados incluindo potencial de 
circuito aberto, espectroscopia de impedância eletroquímica e testes de polarização potenciodinâmica em $\mathrm{NaCl}$ a $0,9 \%$ $(\mathrm{n}=5)$. A caracterização da superfície foi realizada por meio de microscopia eletrônica de varredura (MEV), espectroscopia de energia dispersiva e rugosidade e microdureza de superfície antes e após o teste eletroquímico. Os dados quantitativos foram analisados com nível de significância de 5\%. A densidade de corrente de corrosão e o potencial de corrosão das ligas não apresentaram diferenças estatísticas. Os valores de capacitância das três camadas de óxido, resistência de polarização e impedância de Warburg foram semelhantes entre as ligas. Considerando a topografia, a rugosidade superficial aumentou para todas as ligas no período pós-corrosão. As ligas de aço inoxidável analisadas foram afetadas negativamente no comportamento eletroquímico, cinética de corrosão e caracterização da superfície após a solução de $\mathrm{NaCl}$ a $0,9 \%$ e os ciclos de esterilização em autoclave, confirmando a necessidade de trocas regulares de instrumentos cirúrgicos e brocas usadas em implantologia médica e dentária.

Palavras-chave: Inox; Ligas; Corrosão; Cloreto de sódio; Esterilização.

\section{Resumen}

Este estudio evaluó el efecto de los procedimientos de desinfección y la exposición a ciclos de solución de $\mathrm{NaCl}$ al $0,9 \%$ durante la esterilización, sobre las propiedades electroquímicas, físicas y químicas de diferentes aleaciones de acero inoxidable utilizadas en el campo biomédico. Los discos de aleaciones F899 XM16, F899 303 y F899 420 B se limpiaron con detergente enzimático seguido de 20 ciclos de esterilización en autoclave. Se realizaron pruebas electroquímicas que incluyeron potencial de circuito abierto, espectroscopia de impedancia electroquímica y pruebas de polarización potenciodinámica en $\mathrm{NaCl}$ al $0,9 \%(n=5)$. La caracterización de la superficie se realizó mediante microscopía electrónica de barrido (SEM), espectroscopía de dispersión de energía y rugosidad y microdureza de la superficie antes y después de la prueba electroquímica. Los datos cuantitativos se analizaron con un nivel de significancia del 5\%. La densidad de la corriente de corrosión y el potencial de corrosión de las aleaciones no presentaron diferencias estadísticas. Los valores de capacitancia de las tres capas de óxido, la resistencia a la polarización y la impedancia de Warburg fueron similares entre las aleaciones. Teniendo en cuenta la topografía, la rugosidad de la superficie aumentó para todas las aleaciones en el período posterior a la corrosión. Las aleaciones de acero inoxidable analizadas se vieron afectadas negativamente en el comportamiento electroquímico, cinética de corrosión y caracterización de la superficie después de la solución de $\mathrm{NaCl}$ al $0,9 \%$ y los ciclos de esterilización en autoclave, lo que confirma la necesidad de intercambios regulares de instrumentos quirúrgicos y fresas utilizados en implantología médica y dental.

Palabras clave: Acero inoxidable; Aleaciones; Corrosión; Cloruro de sodio; Esterilización.

\section{Introduction}

Stainless steel is mainly composed of iron (Fe) and a minimum of $11 \%$ (in wt.\%) of chromium $(\mathrm{Cr}$ ); and may also contain several other elements such as nickel (Ni), molybdenum (Mo), and manganese (Mn) (Hedberg, 2015; Sedriks, 1996; Hedberg \& Wang 2013). The stainless steels alloys possess mechanical properties, such as hardness and corrosion resistance, that are dependent on their chemical composition. Therefore, considering their industrial and practical application, different alloys can be applied. (Hedberg, 2015; Sedriks, 1996; Hedberg, et al., 2013; Agrawal, et al., 2015)

Stainless steels are widely employed in the nuclear, chemical, and petrochemical industries4. Specific classes of steels are used in the biomedical industry owing to their biocompatibility and function, high resistance to corrosion, and less release of metallic ions to the organism in addition to the reduced bacterial adhesion (Hedberg, 2015; Hedberg, et al., 2013; Hallab, et al., 2000; Jacobs, et al., 1998). The main applications of steel in the medical and dental fields include implants (cardiac, orthopedic, and dental) (ISO 5832-1; G108 - 94 ASTM) (Hedberg, 2015) and the manufacture of surgical instruments and drills, such as those used in implantology (ASTM F899 - 12b Standard Specification for Wrought Stainless Steels for Surgical Instruments).

There are two main international bodies responsible for the classification of metals and their alloys: ASTM (American Society for Testing and Materials) and AISI (American Iron and Steel Institute). However, the UNS classification (Numbering System for Metals and Alloys) (ASTM F899 - 12b Standard Specification for Wrought Stainless Steels for Surgical Instruments) is considered as a universal reference. ISO 7153-1 specifies that Class 3 (austenitic), 4 (martensitic), 5 (hardened by precipitation), and 6 (ferritic) steels can be used in the manufacture of surgical, medical, and dental instruments. Moreover, these steels can also be applied in the manufacture of sharp and non-sharp medical and dental instruments (Table 1). 
Table 1. Classification of alloys of stainless steels and their applications according to ASTM F899-12b.

\begin{tabular}{|c|c|c|c|c|c|}
\hline Alloys & UNS* & Classification & $\mathbf{n}$ & Sharp instruments & Non-sharp instruments \\
\hline XM16 & S45500 & $\begin{array}{l}5 \text { (hardened by } \\
\text { precipitation) }\end{array}$ & 5 & Scissors & Drills and needles \\
\hline 303 & S30300 & 3 (Austenitic) & 5 & Chisel, curette & $\begin{array}{l}\text { Cannula, staples, drills, } \\
\text { forceps, probes, } \\
\text { hammers, retractors }\end{array}$ \\
\hline 420B & S42000 & 4 (Martensitic) & 5 & $\begin{array}{l}\text { Chisel, rongeur forceps, } \\
\text { forceps, scissors, curettes }\end{array}$ & $\begin{array}{l}\text { Staples, hooks, needles, } \\
\text { retractors }\end{array}$ \\
\hline
\end{tabular}

The drills used in the implant surgeries are extensively used in dental applications (Porto, et al., 2015; Allsobrook, et al., 2011). Some manufacturers suggest that the life span of the drills is approximately ten surgical procedures (Allsobrook, et al., 2011; Chacon, et al., 2006; Tsaousis, et al., 2016). To ensure safe treatment and to prevent cross-contamination, an efficient sterilization process is necessary (Porto, et al., 2015; Allsobrook, et al., 2011; Fais, et al., 2009). Autoclave sterilization, combined with prior cleaning and disinfection, is the most sensitive and safe method for eliminating all viable microorganisms, including bacterial spores (Porto, et al., 2015; Fais, et al., 2009; Wilson, S. Nayak, 2012; Rutala, et al., 2016). However, repeated cycles of autoclave sterilization may cause undesirable changes in the physical properties of the instruments, such as increased surface roughness (Isac, et al., 2015; Batista Mendes, et al., 2014), changes in instrument temperature (Porto, et al., 2015; Chacon, et al., 2006), and reduction in cutting capacity (Fais, et al., 2009); these changes mostly result from the corrosion process that can affect stainless steels (Porto, et al., 2015; Isac et al., 2017; Valois, et al., 2008).

Bone necrosis at the site of osteotomy can occur due to overheating of drills or a surgical technique of milling at excessive speeds; therefore, effective and abundant irrigation, usually performed with a saline solution, is necessary to prevent peri-implant bone loss (Batista-Mendes, et al., 2014; Bullon, et al., 2015). Despite the high resistance of stainless steels to aggressive environments such as seawater, certain foods, body fluids, or solutions containing $\mathrm{Cl}$ - ions, their corrosion resistance can be drastically reduced because of the rupture of the $\mathrm{Cr}$ oxide layer formed on the steel surface (Hedberg \& Wallinder, 2015; Allsobrook, et al., 2011). Thus, an inappropriate choice of the stainless steel class for manufacturing surgical instruments may favor the corrosion process, which increases the probability of loss of the function of the instruments and/or drills.

Therefore, the present study aims to investigate and compare the electrochemical, physical and chemical properties of three different groups of stainless steel alloys (XM16, 303, and 420B) as a function of sterilization processes including autoclaving and exposure to a saline solution $(0.9 \% \mathrm{NaCl})$. The null hypotheses are as follows: (1) There will be no difference in the pattern and corrosion resistance among the different metal alloys in the intergroup comparison. (2) There will be no difference in the surface characterization for each of the alloys in the baseline and post-corrosion periods. (3) There will be no difference in the microhardness of each alloy in the baseline and post-corrosion periods.

\section{Methodology}

\section{1 study design}

Fifteen discs ( $8 \mathrm{~mm}$ in diameter and $3 \mathrm{~mm}$ thickness) were made from three different stainless steel alloys (XM16, 303, and 420B) as per the ASTM F899 standard. Discs were subjected to standard metallography techniques to obtain a mirrorfinished surface. Then, a cleaning process with an enzymatic detergent followed by 20 cycles of autoclave sterilization were performed on the discs and, finally, an electrochemical test was performed to understand the behavior of the stainless steel 
alloys against the saline solution $(0.9 \% \mathrm{NaCl})$. The surface and microhardness analyses were performed in two periods: baseline (before the electrochemical test) and post-corrosion (after the electrochemical test). The study design is described at Figure 1.

Figure 1. Study design.

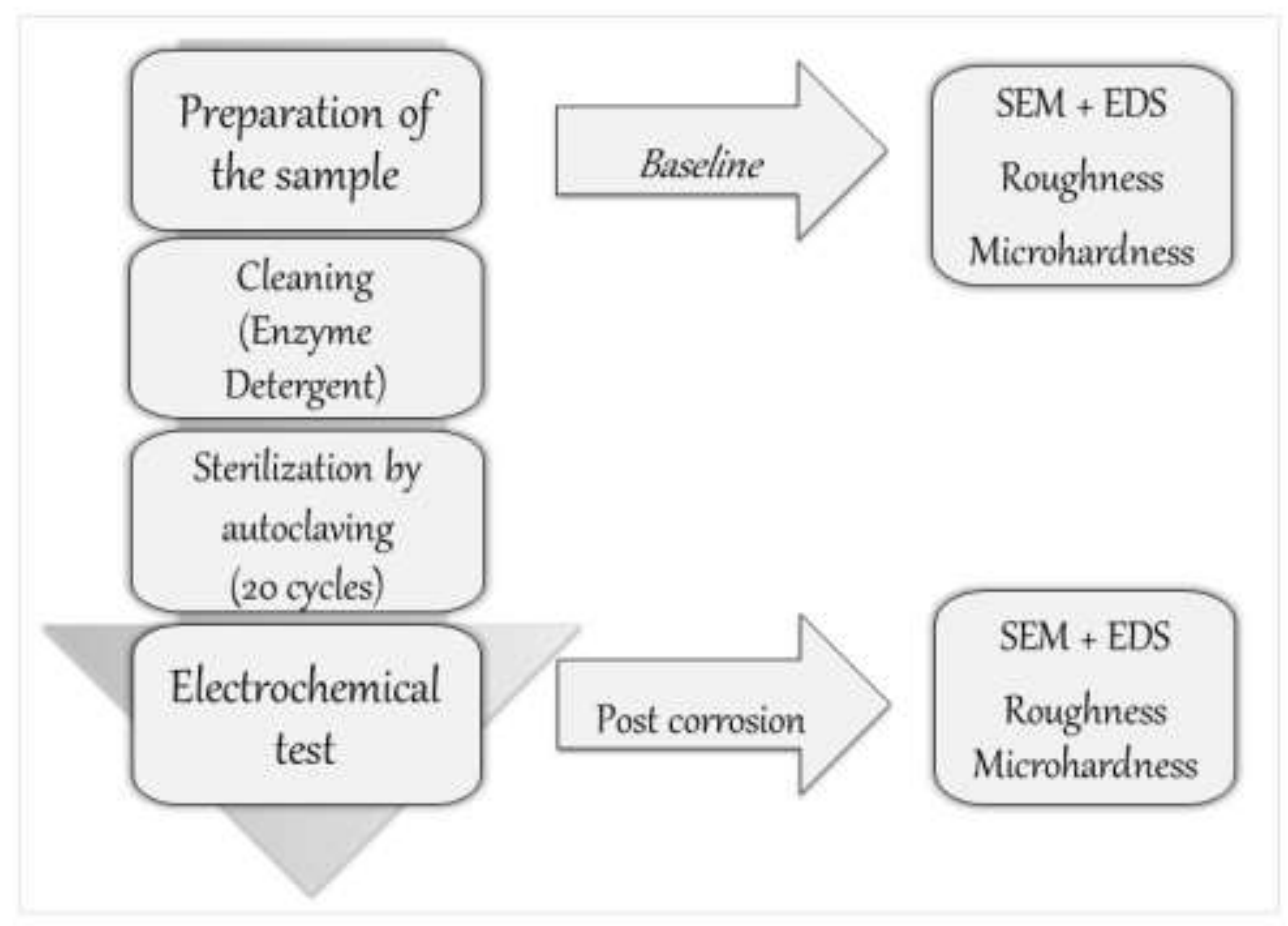

Source: Authors.

\subsection{Preparation of discs}

Discs were polished using standardized metallography techniques with sequential sandpaper (\#320, \#400, \#600, and \#800) (Carbimet 2, Buehler, Lake Bluff, IL, USA) in an automatic polisher (ECOMET® 250PRO/Grinder-polisher AUTOMET 250, Buehler). Then, they were ultrasonically cleaned in distilled water for $10 \mathrm{~min}$. The discs were then polished with a cloth (TextMet Polishing Cloth, Buehler), diamond paste (MetaDi 9-micron, Buehler), and lubricant (MetaDi Fluid, Buehler). Subsequently, they were mirror-finished with a rubber disc (Chemomet I, Buheler) and colloidal silica (MasterMed, Buehler). Finally, the discs were degreased and cleaned with deionized water and $70 \%$ propanol and hot air dried. The surface roughness of all specimens was determined to provide standardization in the finishing of the discs.

\subsection{Cleaning and sterilization process}

Discs were subjected to automated cleaning and disinfection for $5 \mathrm{~min}$ at $37{ }^{\circ} \mathrm{C}$ in an ultrasonic vessel with distilled water containing enzymatic detergent (Riozyme ${ }^{\circledR}$ IV and Neutro, Pharmaceutical Industry Rioquímica, SP, Brazil) $(1 \mathrm{~mL}$ per liter of water, as recommended by the manufacturer). The discs were then abundantly washed with distilled water, dried and finally subjected to autoclave steam sterilization (Vitale Plus 21, Cristófoli Biosecurity - PR - Brazil) for 30 min at $121{ }^{\circ} \mathrm{C}$ and $118 \mathrm{kPa}$, followed by drying for $40 \mathrm{~min}$; only distilled water was used for the process. The sterilization process was repeated 20 times, with the specimens being cooled between the cycles; thus, it simulates the use of the same material for 20 times.

The sterilization process was monitored using physical, chemical and biological indicators. The physical indicators 
are the temperature and pressure of the autoclave. The autoclave tape $1222\left(3 \mathrm{M}^{\mathrm{TM}}\right.$ Comply ${ }^{\mathrm{TM}}, 3 \mathrm{M}, \mathrm{SP}$, Brazil $)$ and the markers of the surgical-grade paper itself were considered chemical indicators, which in turn are Class 1 indicators (as defined by ISO 11140-1: 2014), and their purpose is to differentiate between exposed and unexposed samples, not to ensure sterilization. Finally, biological indicators consisted of a population of bacterial spores of Geobacillus stearothermophillus (ATCC 7953), self-contained for steam sterilization (SporTest; SPS medical - USA) to evaluate the effectiveness of the process. The test was performed in a mini-incubator, following the manufacturer's recommendations.

\subsection{Electrochemical behavior study}

The tests were conducted on a polysulfone electrochemical cell. All the measurements were performed using a standardized three-cell electrode system, according to the instructions of the American Society for Testing Materials (ASTM) (G61 e G31-72). A potentiostat (Interface 1000 Potentiostat/Galvanostat/ZRA, Gamry Instruments, Warminster, PA, USA) connected to a microcomputer was used to perform the electrochemical study. A saturated calomel electrode (SCE) was used as a reference electrode (RE), a graphite rod as a counter electrode (CE) or auxiliary electrode, and the exposed surface of the disc of each alloy (XM16, 303, and 420B) as the working electrode.

The electrolyte used was saline $(0.9 \% \mathrm{NaCl})(10 \mathrm{~mL} ; \mathrm{pH}$ 6.5) (Sigma-Aldrich, MO, USA). In this environment, body fluids can be simulated as human blood plasma, which is composed of $0.9 \% \mathrm{NaCl}$ and other inorganic salts 21 , besides it is the main solution used for irrigation in surgical procedures, aiming to reduce high temperatures generated during osteotomies (Allsobrook, et al., 2011; Batista Mendes, 2014; Bullon, et al., 2015).

Initially, the discs were subjected to a cathodic potential $(-0.9 \mathrm{~V}$ vs. SCE) to guarantee a standardization of the surface oxide layer of the discs. Open circuit potential (OCP) was monitored for $3600 \mathrm{~s}$ to evaluate the potential of the material to the solution and to stabilize the system. Electrochemical impedance spectroscopy (EIS) was used to investigate the electrochemical formation of the oxide layer on the metal surfaces and the associated properties (corrosion kinetics). In EIS, the electrochemical process can be represented by an equivalent electric circuit and the properties of the oxide film (capacitance and resistance) were quantified to determine the corrosion process. The EIS measurements were obtained at a frequency of $100 \mathrm{kHz}$ at $5 \mathrm{mHz}$, with the $\mathrm{AC}$ curve at an amplitude of $10 \mathrm{mV}$ applied to the electrode at its corrosion potential after OCP stabilization for 3600 s (Barão, et al., 2011; Barão et al., 2012; Mathew, et al., 2012; Beline, et al., 2016). These values were used to determine the real (Z') and imaginary (Z') components of the impedance, at which the Nyquist plot or total impedance $(|Z|)$ and phase angle were plotted. The EIS results were used to model the corrosion process (corrosion kinetics) and to understand the properties of the oxide film deposited on the surface of the discs using the appropriate electric circuit.

Figure 2. Equivalent electrical circuit showing the passivation layers formed during the corrosion process [29].

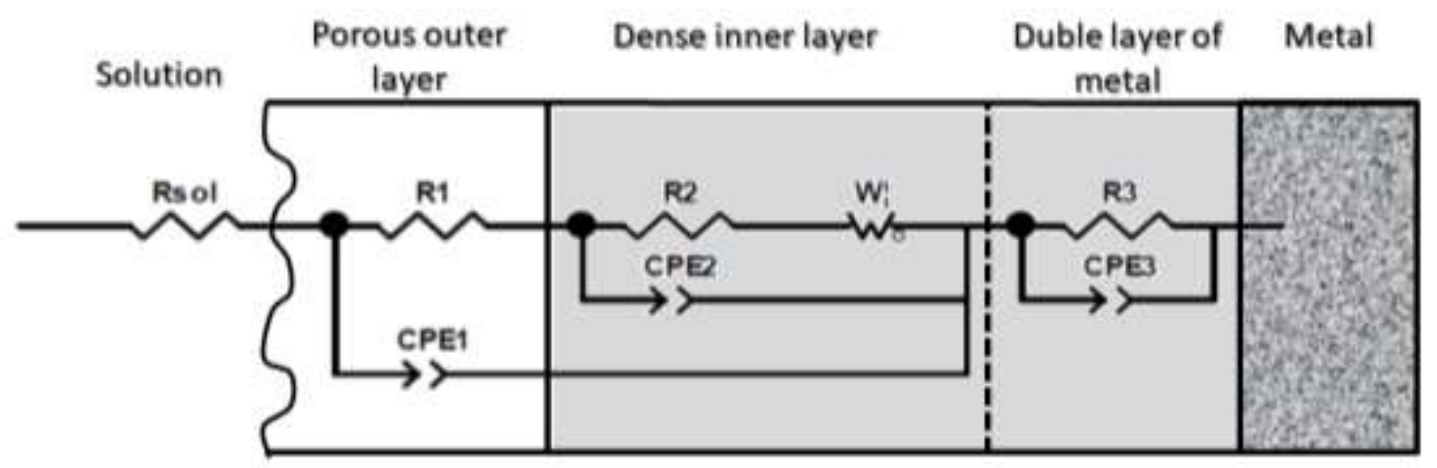

Source: Authors. 
A specific software (Gamry Echem Analyst software, Gamry Instruments) was used to simulate the EIS data. A $\chi^{2}$ value below 0.001 was considered, indicating excellent agreement between the experimental data and adjusted values (Beline, et al., 2016; Xin, et al., 2014).

Finally, the specimens were anodically polarized from $-0.8 \mathrm{~V}$ to $1.8 \mathrm{~V}$ at a scan rate of $2 \mathrm{mV} / \mathrm{s}$. The corrosion parameters were obtained from the potentiodynamic polarization curves. An electrochemical software and the Tafel method were used to investigate the corrosion current density (Icorr), corrosion potential (Ecorr) and corrosion rate (CR) of the steeling steel materials.

\subsection{Surface characterization}

The surface of the XM16, 303, and 420B discs were analyzed by scanning electron microscopy (SEM) (Jeol, model JSM-5600LV, Oregon, USA) to characterize the irregularities present on the surfaces before and after the electrochemical test. Elemental chemical analyses were performed in small volumes, of the order of $1 \mu \mathrm{m} 3$, using energy-dispersive spectroscopy (EDS) (VANTAGE Digital Microanalysis System, Noran Instruments Inc., Middleton, USA). The EDS involves electron microscopic detection of characteristic X-rays produced by each element after a bombardment of the sample with high-energy electrons. Thus, it allows rapid qualitative analysis (mapping) of the main constituent elements of the surfaces of the stainless steel discs in the baseline and post-corrosion periods.

To understand the changes in the surfaces of the alloys of stainless steel upon corrosion, the surface roughness parameter was investigated before (baseline) and after the corrosion process using a rugosimeter (Surftest SJ-400, Mitutoyo, Tokyo, Japan). Each specimen was individually positioned in the center of the equipment and the measuring tip on the surface of the specimen. Three measurements were performed in different areas on each disk (cut-off $0.25 \mathrm{~mm}$ at a velocity of 0.05 $\mathrm{mm} / \mathrm{s}$ ), and the mean value calculated.

The microhardness of the discs was performed in a microdriometer (Shimadzu HMV-2000 Micro Hardness Tester; Shimadzu Corporation, Kyoto, Japão) at room temperature $\left(22 \pm 2^{\circ} \mathrm{C}\right)$ before and after electrochemical tests. The applied load was $500 \mathrm{gF}$ for $15 \mathrm{~s}$ and the microhardness was expressed in unit of Vickers hardness (VHN). The test was repeated four times at four randomized points on the surface of each disc; therefore, the average of these values corresponded to the Vickers microhardness of each specimen.

\subsection{Statistical analysis}

Statistical analysis was performed using a statistical software (SigmaPlot 12.0 - Systat Software, Inc., Chicago, IL, USA). All data were subjected to a normality test (Shapiro-Wilk). Among the corrosion parameters analyzed Ecorr, R2, CPE1, CPE2, and CPE3 were nonhomogeneous $(\mathrm{p}<0.05)$ and were analyzed using the non-parametric Kruskal Wallis test. Icorr, R1, $\mathrm{R} 3$, and $\mathrm{W}$ were homogeneous ( $\mathrm{p}>0.05$ ), and the analysis was performed using the parametric 1-factor analysis of variance (ANOVA). The roughness and microhardness data were within the normality curve ( $p>0.05)$. For the factors (alloys and time) and the interaction (alloys vs. time), a 2 -factor analysis of variance (ANOVA) was applied. The Tukey HSD test was used as a post hoc technique for multiple comparisons between both variables (roughness and microhardness). In this study, with each group containing 5 specimens, the power observed to detect a medium size effect $(0.5$, according to Cohen effect size statistics) was $>0.8$. 


\section{Results and Discussion}

\subsection{Electrochemical stability}

Electrochemical Impedance Spectroscopy

The representation of the EIS data in the Nyquist diagram (Figure 3) shows that the 420B and XM16 alloys showed slight increases in the semicircular diameter of the capacitance loop compared with alloy 303.

Figure 3. Nyquist diagram representing EIS data of XM16, 303 and 420B alloys immersed in $0.9 \%$ saline solution.

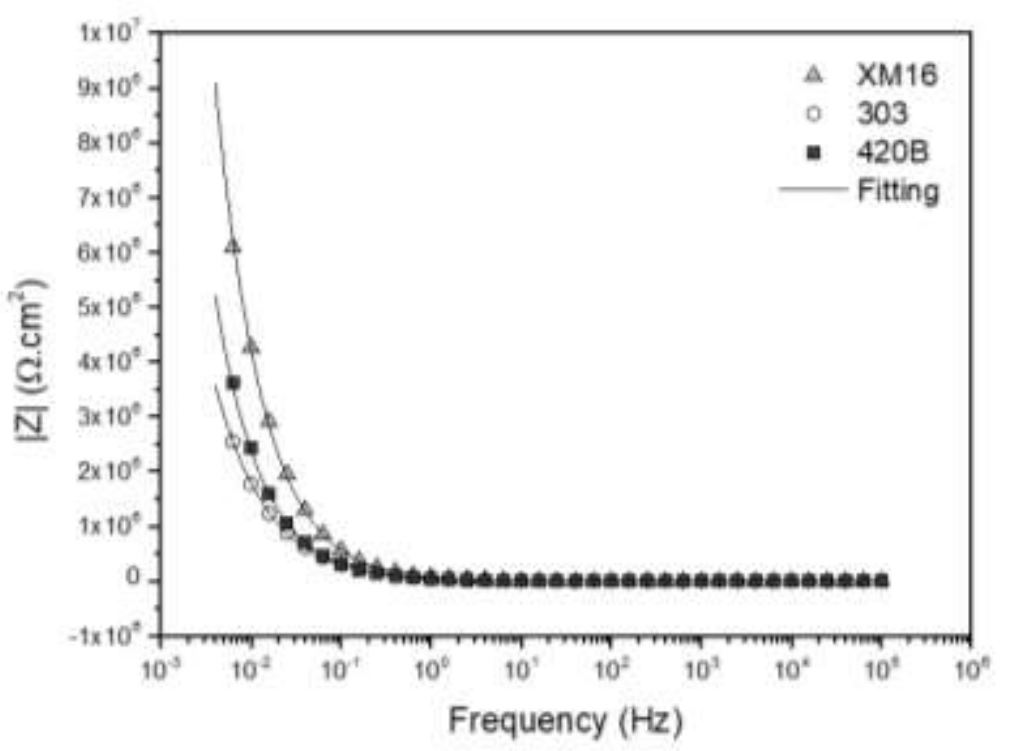

Source: Authors.

In the Bode diagram of impedance $(\mathrm{Z})$ vs. frequency $(\mathrm{Hz})$ (Figure 4), at low frequencies, high impedance values were shown by the XM16 group, while the alloys 420B and 303 exhibited reduced impedance values. 
Figure 4. Impedance module $(|\mathrm{Z}|)$ obtained through the Bode diagram of stainless steel alloys (XM16, 303 and 420B).

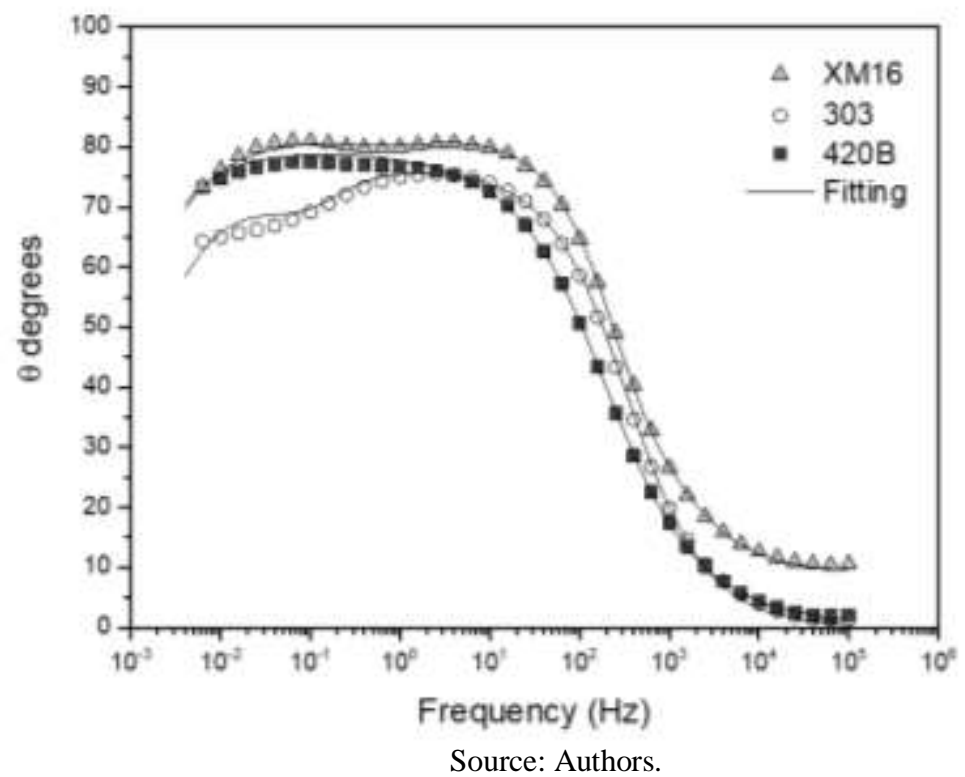

In Figure 5, two time constants was observed for the alloys 303, XM16 and 420B. The phase angles found for the three alloys in the medium frequency regions were $\sim 80^{\circ}$, but in the high-frequency regions, values below $20^{\circ}$ were observed.

Figure 5. Phase angle obtained through the Bode diagram of stainless steel alloys XM16, 303 and 420B

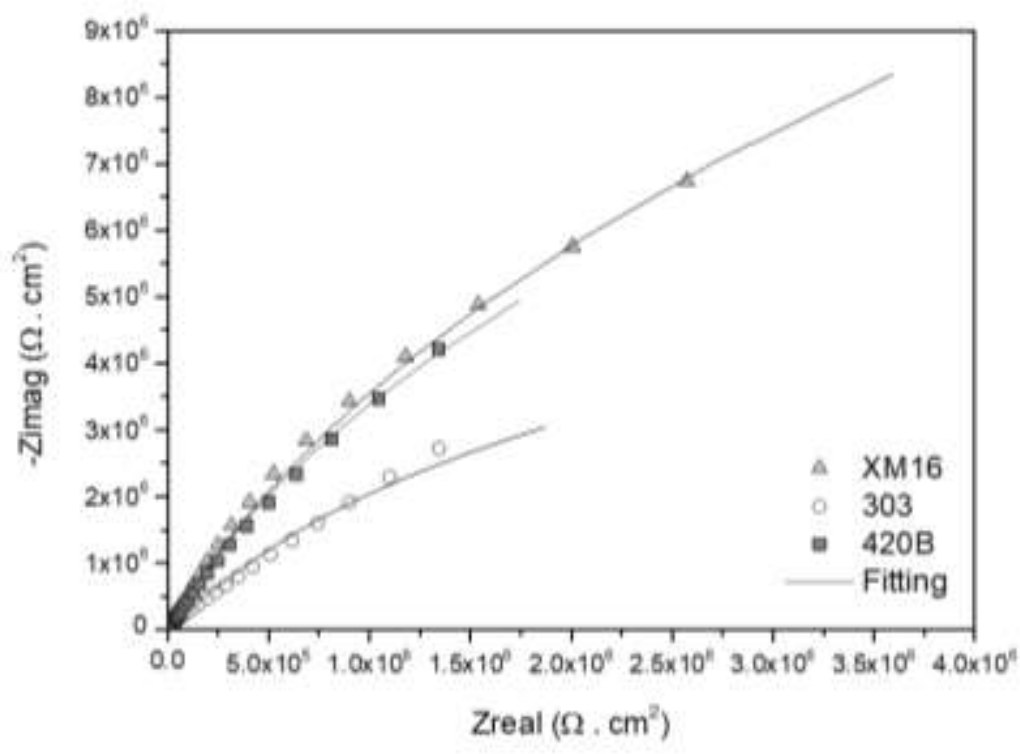

Source: Authors.

The equivalent circuit used to simulate the electrical parameters of the surface is shown in Figure 2. The averages of the resistance parameters $\left(\mathrm{R}_{\mathrm{sol}}, \mathrm{R}_{1}, \mathrm{R}_{2}\right.$, and $\left.\mathrm{R}_{3}\right)$, capacitance $\left(\mathrm{CPE}_{1}, \mathrm{CPE}_{2}, \mathrm{CPE}_{3}\right)$, $\mathrm{W}$ (Porous Bounded Warburg), and $\chi^{2}$ obtained from the equivalent circuit are presented in Table 2. When analyzing the electrical parameters, there was no statistically significant difference ( $p>0.05$ ) in the values obtained for the different alloys. For the variables $\mathrm{R}_{2}, \mathrm{CPE}_{1}, \mathrm{CPE}_{2}$, and $\mathrm{CPE}_{3}$, (the $P$ values were $0.597,0.054,0.093$, and 0.113 , respectively (determined by Kruskal-Wallis), and for R1, R3 and $\mathrm{W}$, the $P$ values were $0.239,0.182$, and 0.208 , respectively, (determined by 1 -factor ANOVA) (Table 2). 
Table 2. Mean (and standard deviation) values of the electrical parameters obtained through the equivalent circuit model for all the alloys.

\begin{tabular}{|c|c|c|c|c|c|c|c|c|c|c|c|c|}
\hline Alloys & $\begin{array}{c}\text { Rsol } \\
\left(\Omega . \mathrm{cm}^{2}\right)\end{array}$ & $\begin{array}{c}\text { R1 } \\
\left(\mathrm{M} \Omega . \mathrm{cm}^{2}\right)\end{array}$ & $\begin{array}{c}\mathbf{R 2} \\
\left(\mathrm{M} \Omega . \mathrm{cm}^{2}\right)\end{array}$ & $\begin{array}{c}\mathbf{R 3} \\
\left(\mathrm{M} \Omega \cdot \mathrm{cm}^{2}\right)\end{array}$ & $\begin{array}{c}\text { CPE1 } \\
(\mathrm{Y} 0) \\
\left(\mu \Omega^{-1} \cdot \mathrm{s}^{\mathrm{n}} \cdot \mathrm{cm}^{2}\right)\end{array}$ & $\eta_{1}$ & $\begin{array}{c}\text { CPE2 } \\
(\mathrm{Y} 0) \\
\left(\mu \Omega^{-1} \cdot \mathrm{s}^{\mathrm{n}} \cdot \mathrm{cm}^{2}\right)\end{array}$ & $\eta_{2}$ & $\begin{array}{c}\text { CPE3 } \\
(\mathrm{Y} 0) \\
\left(\mu \Omega^{-1} \cdot \mathrm{s}^{\mathrm{n}} \cdot \mathrm{cm}^{2}\right)\end{array}$ & $\eta_{3}$ & $\begin{array}{c}\mathbf{W} \\
\left(\Omega . \mathrm{cm}^{2}\right)\end{array}$ & $\chi^{2} \times 10^{-3}$ \\
\hline \multirow{2}{*}{ XM16 } & 455 & 30.090 & 0.490 & 0.684 & \multirow{2}{*}{$2.408(0.406)$} & 0.900 & 26385.700 & 0.540 & -6489.000 & 0.754 & 2.562 & 0.543 \\
\hline & (23) & (4.140) & $(0.482)$ & $(0.643)$ & & $(0.001)$ & $(26104.300)$ & $(0.215)$ & (1858.000) & $(0.197)$ & $(3.072)$ & $(0.077)$ \\
\hline \multirow{2}{*}{303} & 386 & 0.106 & 0.026 & 10.486 & \multirow{2}{*}{$13.049(6.187)$} & 0.900 & 139.115 & 0.678 & -1138.978 & 0.873 & 0.443 & 0.751 \\
\hline & (54) & $(0.082)$ & $(0.021)$ & $(2.727)$ & & $(0.068)$ & $(186.412)$ & $(0.329)$ & (1173.520) & $(0.032)$ & $(0.149)$ & $(0.314)$ \\
\hline \multirow{2}{*}{ 420B } & 363 & 37.515 & $0.007 \times 10^{-3}$ & 0.300 & \multirow{2}{*}{$4.254(0.597)$} & 0.920 & 926.100 & 0.552 & 17451.500 & 0.644 & 5.069 & 0.389 \\
\hline & (2) & (5.395) & $\left(0.005 \times 10^{-3}\right)$ & $(0.179)$ & & $(0.028)$ & (106.900) & $(0.378)$ & (15568.500) & $(0.201)$ & $(5.641)$ & $(0.157)$ \\
\hline
\end{tabular}

Source: Authors. 


\section{Potentiodynamic Polarization Curve}

The polarization curves are shown in Figure 6 and the electrochemical parameters $\mathrm{I}_{\text {corr }}, \mathrm{E}_{\mathrm{corr}}$, and cathodic Tafel curve $\left(b_{c}\right)$, obtained from the Tafel curve, are presented in Table 3.

Figure 6. Potentiodynamic polarization curve (Tafel method) of stainless steel alloys XM16, 303 and 420B

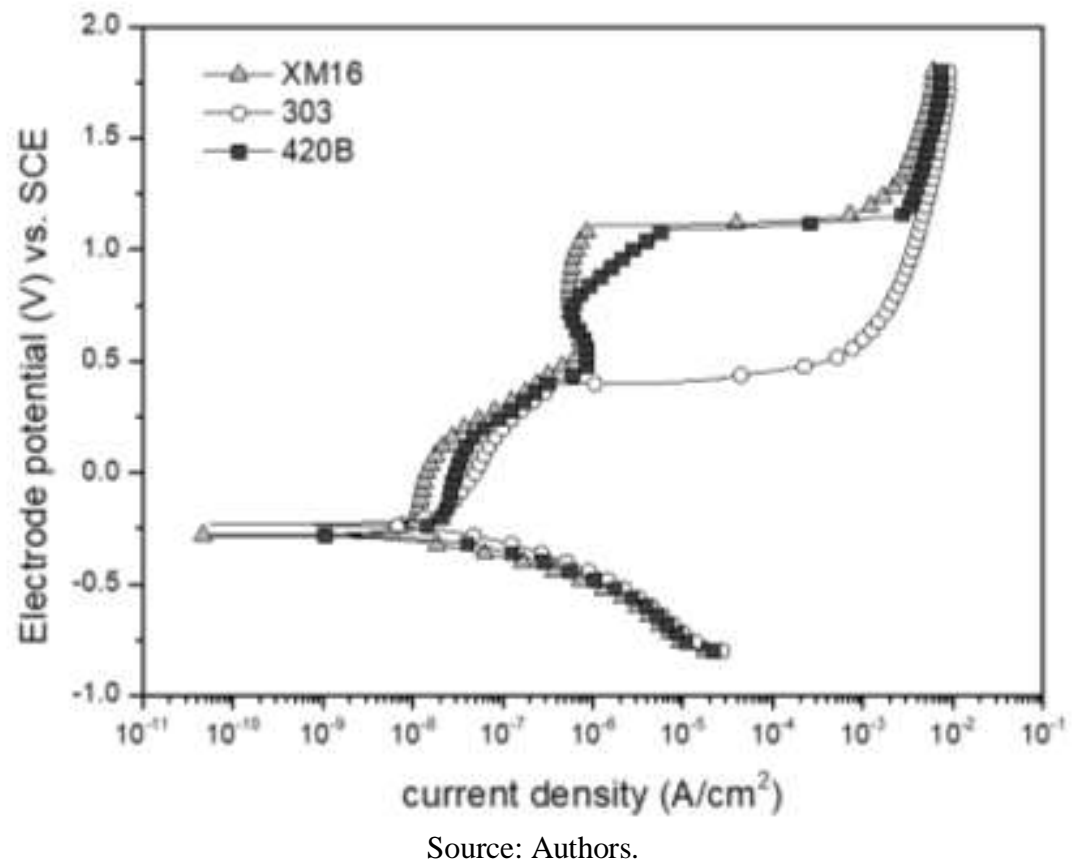

Table 3. Mean (and standard deviation) values of the electrochemical parameters obtained from the potentiodynamic polarization curves of the alloys.

\begin{tabular}{lccc}
\hline Alloys & $\begin{array}{c}\text { Ecorr } \\
(\mathbf{V}) \mathbf{v s} \mathbf{S C E}\end{array}$ & $\begin{array}{c}\text { Icorr } \\
\left(\mathbf{\eta} \mathbf{A} \square \mathbf{c m}^{2}\right)\end{array}$ & $\begin{array}{c}\boldsymbol{b}_{\mathbf{c}} \\
\left(\mathbf{V} \square \mathbf{d e c}^{-\mathbf{1}}\right)\end{array}$ \\
\hline XM16 & $-280.830(4.822)$ & $18.603(5.634)$ & $0.130(0.004)$ \\
$\mathbf{3 0 3}$ & $-274.266(13.914)$ & $20.874(1.140)$ & $0.137(0.007)$ \\
$\mathbf{4 2 0 B}$ & $-257.877(17.340)$ & $26.817(3.222)$ & $0.141(0.005)$ \\
\hline
\end{tabular}

Source: Authors.

No linear relationship was observed in the Tafel curve in the anodic region $\left(b_{a}\right)$ of the tested alloys, thus not allowing the determination of the $\mathrm{I}_{\text {pass }}$ (passivation current density) values. Therefore, the parameters obtained were based on the cathodic region $\left(b_{c}\right)$ of the Tafel curve. In Table 3, we observed similarities in the $\mathrm{E}_{\mathrm{corr}}$ values, corroborating the quantitative results, where there was no statistically significant difference among the three alloys ( $P=0.421$, Kruskal-Wallis). Similarly, no statistically significant differences were found for the $\mathrm{I}_{\text {corr }}$ values ( $P=0.813$, ANOVA 1 factor).

\subsection{Surface characterization}

\section{Scanning Electron Microscopy and Energy Dispersive Spectroscopy}

Figure 7 shows the SEM images, in which we can observe significant surface changes when comparing baseline with post-corrosion periods for all the three alloys. 
Figure 7. Scanning Electron Microscopy of the three alloys of stainless steels (XM16, 303 and 420B). (*) Region exposed to $0.9 \% \mathrm{NaCl}$ during the electrochemical test.

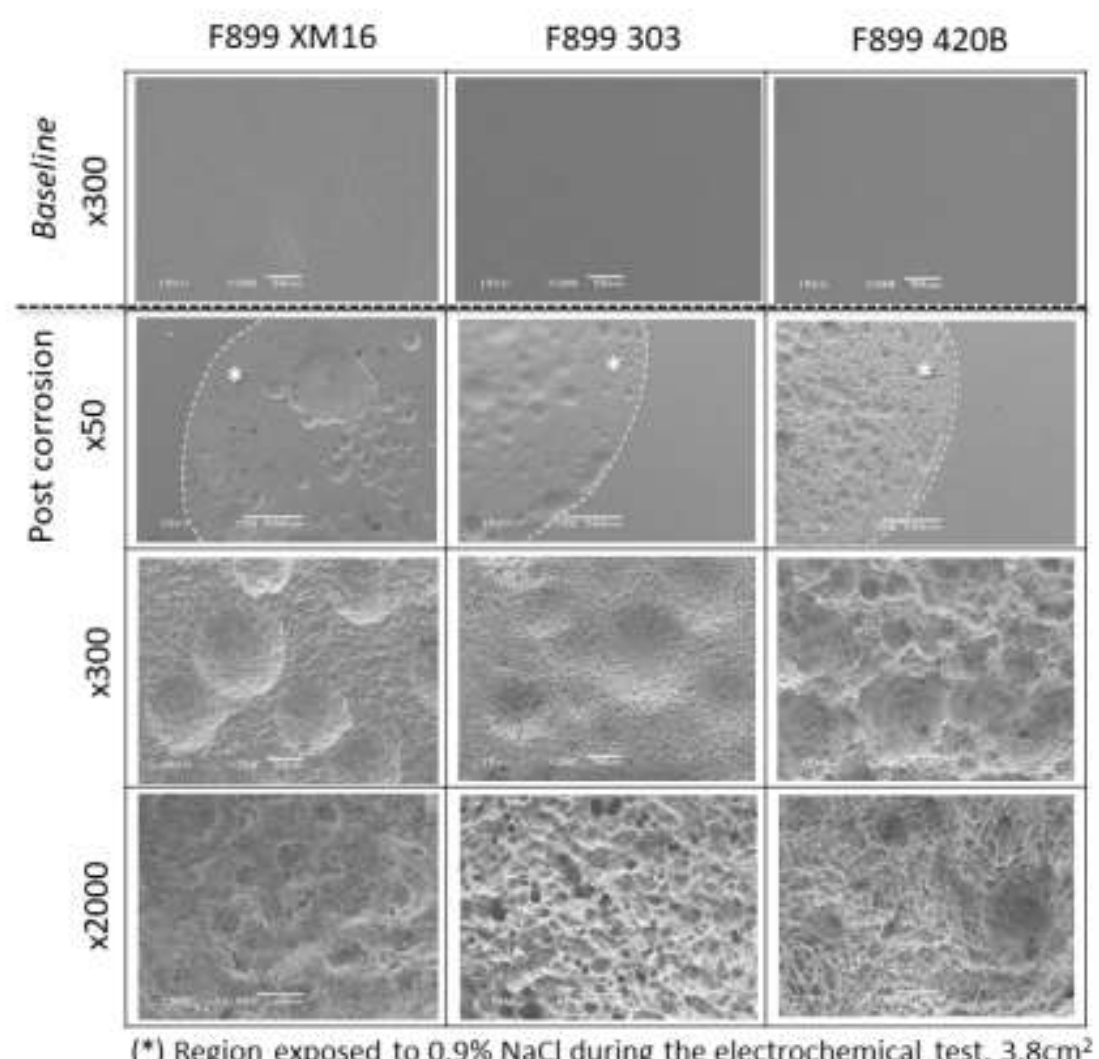

Source: Authors.

In the baseline, homogeneous surfaces with no pores and longitudinal grooves due to the polishing process were noted. On the other hand, in the post-corrosion period, suggestive areas of corrosion was observed. At 50x magnification, a dashed line indicating the corroded $(*)$ and non-corroded regions are presented. The area of exposure of the disc (diameter $=8$ $\mathrm{mm}$ ) to the electrochemical test was $3.8 \mathrm{~mm}^{2}$, located in the center of the specimen. The post-corrosion SEM images with 300x and 2000× magnifications, showed non-homogeneous surfaces with corroded pits and marked reliefs.

Regarding EDS analyiss, one specimen from each group (XM16, 303, and 420B) was analyzed, and three quadrangular regions of each specimen were determined and examined. The average values obtained were used to compare the chemical compositions in the baseline and post-corrosion periods (Figure 8). 
Figure 8. EDS of XM16, 303 and 420B alloys at baseline and post-corrosion periods.

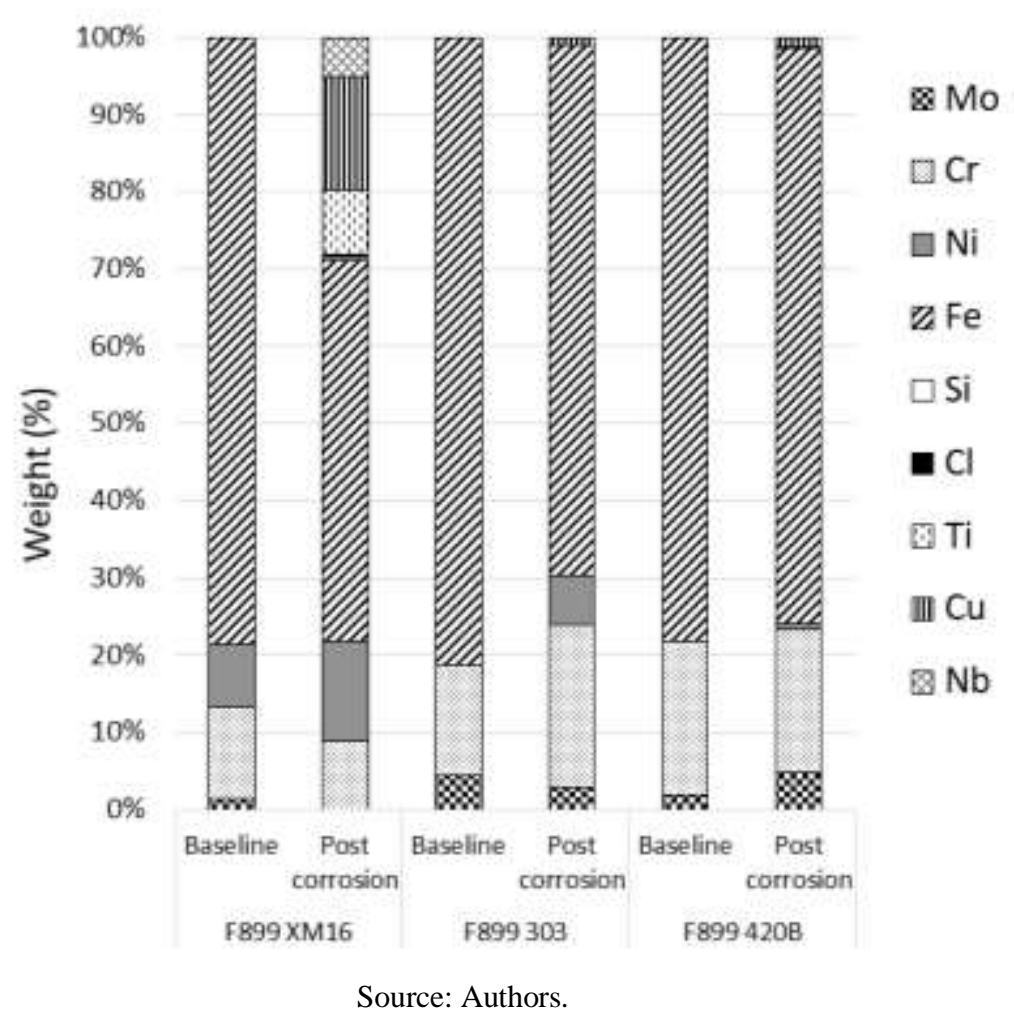

The baseline chemical composition of the XM16 alloy was Fe $78.55 \%$, Cr $11.95 \%$, Ni 8.22\%, and Mo $1.27 \%$. In the 303 and 420B alloys, $\mathrm{Ni}$ was not detected; the corresponding chemical compositions were $\mathrm{Fe} 81.39 \%$, $\mathrm{Cr} 14.28 \%$, and $\mathrm{Mo}$ $4.33 \%$ and $\mathrm{Fe} 78.3 \%, \mathrm{Cr}$ 19.89\%, and Mo 1.81\%. In the post-corrosion period, peaks of different chemical elements were observed mainly for the XM16 alloy, such as Fe (49.36\%), Cu (14.75\%), Ni (12.93\%), Cr (4.94\%), Ti (8.29\%), Nb (5.1\%), Si $(0.44 \%)$, and $\mathrm{Cl}(0.28 \%)$. Minor differences were found in the composition of alloys 303 and $420 \mathrm{~B}$ in the post-corrosion period. For alloy 303, Fe (68.73\%), $\mathrm{Cr}(21.01 \%), \mathrm{Ni}(6.34 \%)$, Mo (2.88\%), Cu (1\%), and Ti (rest) were the components, while those for alloy 420B were $\mathrm{Fe}(74.48 \%), \mathrm{Cr}(18.56 \%)$, Mo (4.77\%), $\mathrm{Cu}(1.32 \%), \mathrm{Ni}(0.48 \%)$, and $\mathrm{Ti}$ (rest).

\section{Surface Roughness and Microhardness}

The Ra values at the baseline and post-corrosion periods are shown in Figure 9. Before the corrosion process, the Ra values were similar among the steeling steel materials $(P>0.05)$. 
Figure 9. Surface roughness (Ra) data of the XM16, 303 and 420B alloys tested at the baseline and post-corrosion periods. Different upper-case letters indicate significant inter-group differences in the same evaluation period. Different lowercase letters indicate significant difference in the different baseline and post-corrosion periods for each alloy (intra-group) $(p<0.05)$

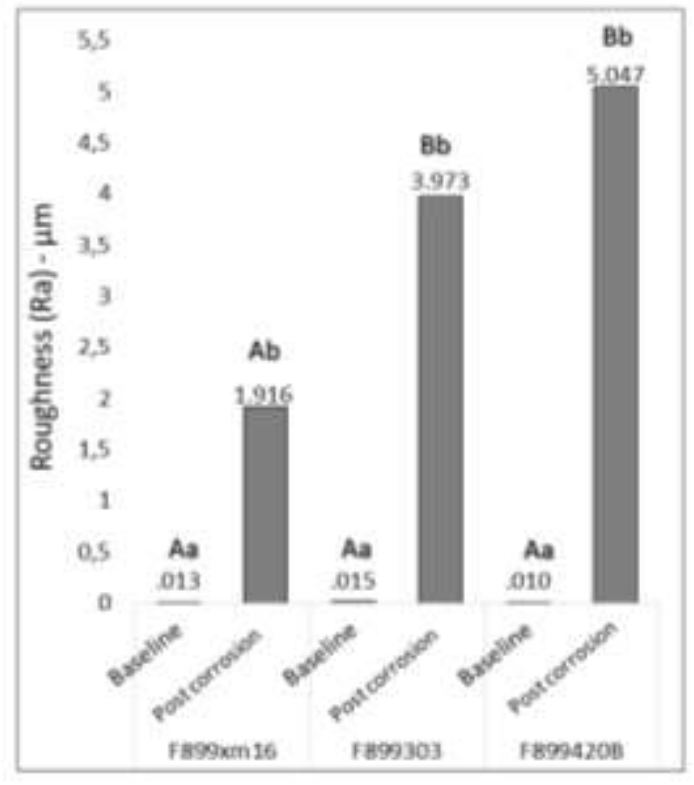

Source: Authors.

However, after the electrochemical test, all the alloys showed increased Ra values when compared to the baseline, with 303 and 420B alloys showing similar Ra values $(P=0.118)$, higher than those found for XM16 $(P<0.001)$.

Vickers microhardness data are shown in Figure 10.

Figure 10. Vickers microhardness data of XM16, 303 and 420B alloys at baseline and post-corrosion periods. Different uppercase letters indicate significant inter-group differences in the same evaluation period. Different lowercase letters indicate significant difference in the different baseline and post-corrosion periods for each alloy (intra-group) $(\mathrm{p}<0.05)$.

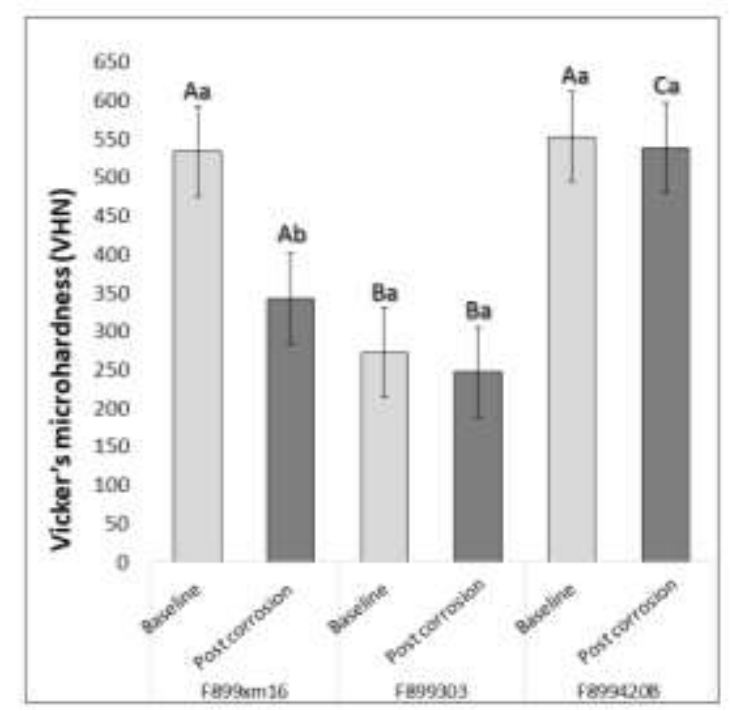

Source: Authors. 
In the baseline period, the XM16 and 420B alloys presented similar microhardness values ( $P=0.687)$, greater than those found for the 303 alloy $(P<0.001)$. The corrosion process reduced the microhardness of the XM16 alloy $(P<0.001)$ while no effect was noted for the other alloys (303 and 420B) $(P>0.05)$. In the post-corrosion period, 420B material had the highest microhardness value with the 303 material the lowest one $(P<0.001)$.

\section{Discussion}

The first null hypothesis was accepted because there was no statistical difference in electrochemical behavior between the different stainless steel alloys exposure of the specimens to the $0.9 \% \mathrm{NaCl}$ solution after the corrosion test. The second hypothesis was rejected, due to the significant increase in the alterations found in the analyses for surface characterization, both in qualitative (scanning electron microscopy and energy-dispersive spectroscopy) and quantitative (surface roughness) data. By the evaluation of Vickers superficial microhardness, the third null hypothesis was rejected because the XM16 alloy showed significant reduction of values, while the alloys 420B and 303 had similar baseline and post-corrosion microhardness values.

The EIS data were analyzed using three methods: Nyquist diagrams, Bode plots (impedance and phase angle), and equivalent circuit. The equivalent circuit model used for simulating surface electrical parameters describes a passivation film with a bilayer structure composed of a dense inner layer and a porous outer layer (Figure 2) (Dadfar, et al., 2016) ${ }^{29}$. The $\chi^{2}$ values obtained were on the order of $10^{-4}$ to $10^{-5}$, indicating that the data obtained experimentally are in agreement with the proposed circuit, corroborating the results obtained in previous studies (Beline, et al., 2016; Beline \& Ida, et al., 2016; Faverani, et al., 2014).

The equivalent electric circuit model used in this study follows that proposed by Dadfar, et al., in which $\mathrm{R}_{\text {sol }}$ represents the resistance of the solution; $\mathrm{R}_{1}$ (resistance to transfer of charge) and $\mathrm{CPE}_{1}$ (constant phase element) are parameters obtained from the porous outer layer of the passivation film; $\mathrm{R}_{2}, \mathrm{CPE}_{2}$, and $\mathrm{W}_{1}$ (porous bounded Warburg) are components corresponding to the dense inner layer of the passivation film; and $\mathrm{R}_{3}$ and $\mathrm{CPE}_{3}$ represent the parameters of the substrate (Dadfar, et al., 2016). The Warburg impedance element indicates the diffusion of ions through the micro pores present in the passivation barrier, that is, the ability to resist ionic changes occurring in the pores (Skale et al., 2007). To fit the data and reduce the surface heterogeneity (Beline, et al., 2016; Sun, et al., 2016), the CPE was used instead of the pure capacitance (Q) in the equivalent circuit. The CPE includes values of Y0 and $\eta$, where $\eta$ describes the behavior of CPE due to the surface roughness acquired during the preparation of the specimens (Xin et al., 2013). When $\eta=-1$, the CPE acts as an inductor; for $\eta$ $=0$, as a pure resistor; for $\eta=1$, as an ideal capacitor (Xin, et al., 2013; Beline, et al., 2016, Luo, et al., 2017) and $\eta=0.5$ represents the Warburg element (Luo, et al., 2017). In our study, the value of $\eta$ in $\mathrm{CPE}_{1}$ ranged from 0.90 to 0.92 ; in $\mathrm{CPE}_{2}, \eta$ oscillated between 0.32 and 0.65 ; and in $\mathrm{CPE}_{3}, \eta$ presented values between 0.7 and 0.87 (Table 3). Thus, $\mathrm{CPE}_{1}$ and $\mathrm{CPE}_{3}$ acted as non-ideal capacitors in the equivalent circuit. Lower values of $\eta$ in $\mathrm{CPE}_{2}$ indicate the formation of a porous structure (Beline, et al., 2016), which can be correlated with the electrochemical circuit model shown in Figure 10.

The polarization resistance parameter $\left(\mathrm{R}_{\mathrm{p}}\right)$, also referred to as the charge transfer resistance, is a suitable measure to verify the stability of the passive layer (Kocijan, et al., 2011). Its value is inversely proportional to the capacitance (CPE), which represents the capacity of the material performing the ion exchange (Beline, et al., 2016; Faverani, et al., 2014). Table 2 shows the resistance and capacitance data of each of these layers, from which we suggest that the porous outer layer presents high resistance $\left(R_{1}\right)$ and reduced capacitance $\left(C P E_{1}\right)$. In the dense inner layer, $R_{2}$ is lower than $R_{1}$ and $R_{3}$. Owing to inverse proportionality, $\mathrm{CPE}_{2}$ presents the highest capacitance values compared to those of the other layers $\left(\mathrm{CPE}_{1}\right.$ and $\left.\mathrm{CPE}_{3}\right)$. In the inner layer, termed the "double layer" of the metal, intermediate values of resistance $\left(\mathrm{R}_{3}\right)$ and capacitance $\left(\mathrm{CPE}_{3}\right)$ are observed. 
However, statistical differences are not obtained for the corrosion parameters between the alloys, which corroborates with the representation of the Nyquist diagram, wherein similar semicircular diameters are observed for all groups.

In the Bode diagram, two time constants are observed for alloys 303, XM16 and 420B (Figure 4 and 5). The occurrence of a time constant in the phase angle indicates the presence of a compact and homogeneous oxide layer, whereas the occurrence of two time constants suggests the presence of a compact inner layer and porous outer layer (Beline, et al., 2016; Faverani, et al. 2014; Jin-long, et al., 2012), compatible with the equivalent electric circuit used in our study. The obtained phase angles for the three alloys in the high-frequency regions are below $20^{\circ}$. This indicates the aggressiveness of the sterilization processes associated with exposure in the $0.9 \% \mathrm{NaCl}$ solution in the stainless steel alloys tested, supporting previous studies (Hedberg \& Wallinder, 2015; Allsobrook, et al. 2011; Bonaccorso, et al., 2008; Luo, et al., 2017; ).

In the analysis of the impedance modulus $(|\mathrm{Z}|)$ versus frequency, in the low-frequency region, the impedance values increase as 303 alloy < 420B alloy < XM16 alloy, suggesting slightly better electrochemical properties for XM16. The lowfrequency region represents the values of polarization resistance associated with the solution resistance, making it the region of interest for electrochemical studies (Beline, et al., 2016; Ribeiro, et al., 2016).

The potentiodynamic polarization curves for alloys of stainless steels exposed to $0.9 \% \mathrm{NaCl}$ present similar shapes. No linear region is observed in the Tafel curve in the anodic region $\left(b_{\mathrm{a}}\right)$ of the alloys tested, i.e., no passivation area is formed. This phenomenon, which is associated with high $\mathrm{I}_{\text {corr }}$ values and corrosion rates, reinforces the aggressiveness of the electrolyte action on the surface of the discs (Beline, et al., 2016; Beline, et al., 2016; Luo, et al., 2016). The electrochemical parameters evaluated $-E_{\text {corr }}$ and $I_{\text {corr }}$ - show no statistical difference between the alloys. Positive values of $E_{\text {corr }}$ provide better performance in corrosion resistance (Beline, et al., 2016; Beline, Ida, et al., 2016; Faverani, et al., 2014; Cui, et al., 2015); however, in our study, significantly electronegative values were found for $\mathrm{E}_{\mathrm{corr}}$ in the three alloys, indicating a greater tendency for corrosion.

The surface finish has an important function in the corrosion resistance. The lower the initial values of Ra, the lower the tendency for corrosion (McGuire, et al., 2018). Analysis of the baseline surface roughness of the alloys tested in this study revealed similar values of Ra between the alloys. However, after subjecting the surfaces of the discs to disinfection processes, repeated sterilization cycles, and electrochemical tests, surface changes were observed macro and microscopically, indicating corrosive attack on all the evaluated specimens. Statistical analyses confirmed significantly higher values of Ra in the postcorrosion period for all specimens and similar corrosion parameters between the alloys. Autoclave sterilization may have contributed to the increased surface roughness and poor electrochemical behavior, in accordance with Batista Mendes, et al. 2014.

Pitting corrosion is a localized corrosion process occurring in stainless steels (Hedberg \& Wallinder, 2015; Bonaccorso, et al., 2008). Microregions of the surface are affected by pitting corrosion, and because of the aggressive medium formed from the products of electrochemical reactions; an increase in their size is expected. In our study, the electrolyte used for the reactions was $0.9 \% \mathrm{NaCl}$ solution, the chloride ions (Cl-) of which compete with oxygen and rupture the integrity of the protective layers, thereby favoring corrosion (Hedberg \& Wallinder, 2015; Bonaccorso, et al., 2008).

Corrosion weakens the internal structure of surgical instruments and drills due to the appearance of corrosion pits, which have deep morphology in very limited areas (Isac, et a., 2015; Batista Mendes, et al., 2014), and may culminate in possible fractures during clinical use. In a study evaluating the fracture of dental implants simulating masticatory loading in different media, $0.9 \% \mathrm{NaCl}$ was the solution that presented greater aggressiveness, with early implant failures (Shemtov-Yona, et al., 2016). The lower values of the Vickers microhardness in the post-corrosion period contributed to the reduction of the material resistance, with a consequent decrease in the longevity of the drills and instruments (Beline \& Ida, et al., 2016). In addition, high values of Ra favored bacterial adhesion (Hedberg, et al., 2013), making disinfection and cleaning difficult and increasing the risks of cross contamination. 
On rough surfaces, the direction of emitted X-rays can often deviate from the ideal linear absorption path obtained with a flat sample, enabling the identification of peaks of different chemical elements (Newbury, et al., 2013). This may justify the phenomenon occurring in this study, whereby for all the alloys, more chemical elements were detected after the electrochemical test. A higher $\mathrm{Cr}$ (wt\%) content leads to the formation of a layer of chromium oxide $\left(\mathrm{Cr}_{2} \mathrm{O}_{3}\right)$ on the surface of the metals, thereby imparting a higher corrosion resistance to the alloys. This generally results in a lower total amount of metals (dominated by Fe), but not necessarily in a smaller amount of $\mathrm{Cr}$, Ni, Mn, or Mo released (Hedberg, et al., 2015).

The composition of the metal alloys contributes to specific properties such as longevity, ability to cut drill bits/surgical instruments, and corrosion resistance (Batista Mendes, et al., 2014; Bullon, et al., 2015). An electrochemical process can become active due to inappropriate selection of the alloy for environments with corrosive characteristics (Hedberg, et al., 2015). However, the application of 420B for the preparation of drills has not been described by ASTM F899-12b. In the literature, we found studies employing alloy 420B in milling cutters for dental implants. As some manufacturers have suggested that the life of implant cutters is approximately 10 surgical procedures (Allsobrook, et al., 2011; Chacon, et al., 2006; Tsaousis, et al., 2016), in the present study, 20 sterilization cycles were performed to simulate multiple use and analyze the consequent microstructural and electrochemical changes.

In a study comparing the mechanical properties, wear resistance, and corrosion resistance between implants made with 440 (Straumann ${ }^{\circledR}$ ) and 420B alloys, better characteristics were presented by 420B, suggesting the possibility of a $20 \%$ greater use of drills made using 420B (Bullon, et al., 2017). Another study considered milling cutters from three worldrenowned implant systems, composed of stainless steel (Straumann ${ }^{\circledR}$ and Neoss ${ }^{\circledR}$ ) and tungsten-coated stainless steel (Nobel Biocare $\left.{ }^{\circledR}\right)$, wherein all were subjected to multiple sterilization processes and irrigation with saline solution to simulate the repeated use of drill bits. The authors concluded that tungsten-coated milling cutters showed minimal surface changes, less corrosion, and lower temperature elevations during milling even after 20 osteotomies (Allsobrook, et al., 2011). Hence, new studies are necessary for new alloys or metal coatings to improve surgical instruments and milling, to provide greater resistance to routine dental procedures, which are aggressive to stainless steels, such as steam sterilization and saline irrigation.

Knowledge of the mechanisms involved in the simultaneous actions of use, wear and corrosion makes it possible to predict with greater precision the longevity of the materials for procedures with regular conditions (Dalmau, et al., 2016). A limitation of the present study for the simulation of dental drills is the use of the discs in static form; drills and milling cutters in an implant are utilized and analyzed dynamically, with different rotations and pressures employed by surgeons, bone resilience, and bone resiliency depending on the anatomical location for implanting. Therefore, we suggest that future studies combining the effect of corrosion and wear should be carried out to verify the performance of the alloys tested in this study.

\section{Conclusion}

In conclusion, the stainless steel alloys XM16, 303 and 420B were negatively affected at the electrochemical behavior, corrosion kinetics, and surface characterization after the $0.9 \% \mathrm{NaCl}$ solution and the autoclave sterilization cycles and similar electrochemical behavior and surface characteristics were found for the three alloys, confirming the need for regular exchanges of surgical instruments and drills used in medical and dental implantology.

\section{Acknowledgment}

The authors acknowledge DSP Biomedical ${ }^{\circledR}$ for the donation of the alloy discs; Prof. Dr. Alberto Carlos Botazzo Delbem from the Laboratory of Pediatric Dentistry, Department of Child and Social Dentistry at Aracatuba Dental School - 
Sao Paulo State Univ, for the Vickers microhardness facility; and Prof. Dr. Paulo Henrique dos Santos from the Department of Dental Materials and Prosthesis at Aracatuba Dental School - Sao Paulo State Univ for the rugosimeter facility.

The manuscript has not been published, simultaneously submitted, or already accepted for publication elsewhere, and that all authors have read and approved the submitted version of the manuscript.

\section{References}

Agrawal, H., \& Sharma, P., Tiwari, P., Taiwade, R. V., Dayal, R. K. (2015). Evaluation of Self-Healing Behaviour of AISI 304 Stainless Steel. Transactions of the Indian Institute of Metals, 68(4):501-511. 10.1007/s12666-014-0467-7.

Allsobrook, O. F., Leichter, J., Holborrow, D., \& Swain, M. (2011). Descriptive study of the longevity of dental implant surgery drills. Clinical implant dentistry and related research, 13(3), 244-254. 10.1111/j.1708-8208.2009.00205.x

Al Jabbari, Y., Fournelle, R., Ziebert, G., Toth, J., \& Iacopino, A. (2008). Mechanical behavior and failure analysis of prosthetic retaining screws after longterm use in vivo. Part 2: Metallurgical and microhardness analysis. Journal of prosthodontics: official journal of the American College of Prosthodontists, 17(3), 181-191. 10.1111/j.1532-849X.2007.00271.x

Barão, V. A., \& Mathew, M. T., Assunção, W. G, Yuan, J. C., Wimmer, M. A., Sukotjo, C. (2011). The role of lipopolysaccharide on the electrochemical behavior of titanium. Journal of Dental Research, 90(5), 613-8. 10.1177/0022034510396880.

Barão, V. A., Mathew, M. T., Assunção, W. G., Yuan, J. C., Wimmer, M. A., \& Sukotjo, C. (2012). Stability of cp-Ti and Ti-6Al-4V alloy for dental implants as a function of saliva $\mathrm{pH}$ - an electrochemical study. Clinical oral implants research, 23(9), 1055-1062. 10.1111/j.1600-0501.2011.02265.x

Batista Mendes, G. C., Padovan, L. E., Ribeiro-Júnior, P. D., Sartori, E. M., Valgas, L., \& Claudino, M. (2014). Influence of implant drill materials on wear, deformation, and roughness after repeated drilling and sterilization. Implant dentistry, 23(2), 188-194. 10.1097/ID.0000000000000028

Beline, T., Garcia, C. S., Ogawa, E. S., Marques, I., Matos, A. O., Sukotjo, C., Mathew, M. T., Mesquita, M. F., Consani, R. X., \& Barão, V. (2016). Surface treatment influences electrochemical stability of cpTi exposed to mouthwashes. Materials science \& engineering. C, Materials for biological applications, 59 , 1079-1088. 10.1016/j.msec.2015.11.045

Beline, T., Marques, I., Matos, A. O., Ogawa, E. S., Ricomini-Filho, A. P., Rangel, E. C., da Cruz, N. C., Sukotjo, C., Mathew, M. T., Landers, R., Consani, R. L., Mesquita, M. F., \& Barão, V. A. (2016). Production of a biofunctional titanium surface using plasma electrolytic oxidation and glow-discharge plasma for biomedical applications. Biointerphases, 11(1), 011013. 10.1116/1.4944061

Bonaccorso, A., Tripi, T. R., Rondelli, G., Condorelli, G. G., Cantatore, G., \& Schäfer, E. (2008). Pitting corrosion resistance of nickel-titanium rotary instruments with different surface treatments in seventeen percent ethylenediaminetetraacetic Acid and sodium chloride solutions. Journal of endodontics, 34(2), 208-211. doi.org/10.1016/j.joen.2007.11.012

Bullon, B., Bueno, E. F., Herrero, M., Fernandez-Palacin, A., Rios, J. V., Bullon, P., \& Gil, F. J. (2015). Effect of irrigation and stainless steel drills on dental implant bed heat generation. Journal of materials science. Materials in medicine, 26(2), 75. 10.1007/s 10856-015-5412-8

Ciuccio, R.L., \& Garbulha, D., Lopes, F., \& Oliveira., M. D. (2011). Children with cochlear implants: communication skills and quality of life. Innovations implant journal: biomaterials and esthetics, 4. 10.1590/S1808-86942012000100003.

Cui, S., \& Yin, X., Yu, Q., Liu, Y., Wang, D., \& Zhou. F. (2015). Polypyrrole nanowire/TiO2 nanotube nanocomposites as photoanodes for photocathodic protection of Ti substrate and 304 stainless steel under visible light. Corrosion Science, 98:471-477. 10.1016/j.corsci.2015.05.059.

Dalmau, A., \& Rmili, W., Richard, C., \& Igual-Muñoz. A. (2016). Tribocorrosion behavior of new martensitic stainless steels in sodium chloride solution. Wear, 368-369:146-155. 10.1016/j.wear.2016.09.002.

Dadfar, M., \& Salehi, M., Golozar, M. A., \& Trasatti, S. (2016). Surface modification of 304 stainless steels to improve corrosion behavior and interfacial contact resistance of bipolar plates. International Journal of Hydrogen Energy, 41:21375-21384.

Fais, L. M., \& Pinelli, L. A., Adabo, G. L., et al. (2009). Influence of microwave sterilization on the cutting capacity of carbide burs. Journal of Applied Oral Science, 17(6):584-589. 10.1590/s1678-77572009000600009.

Faverani, L. P., Barao, V. A., Pires, M. F., Yuan, J. C., Sukotjo, C., Mathew, M. T., \& Assunção, W. G. (2014). Corrosion kinetics and topography analysis of Ti-6Al-4V alloy subjected to different mouthwash solutions. Materials science \& engineering. C, Materials for biological applications, 43, 1-10. 10.1016/j.msec.2014.06.033

Hallab, N., Jacobs, J. J., \& Black, J. (2000). Hypersensitivity to metallic biomaterials: a review of leukocyte migration inhibition assays. Biomaterials, 21(13):1301-14. 10.1016/s0142-9612(99)00235-5.

Hedberg, Y. S., \& Odnevall Wallinder, I. (2015). Metal release from stainless steel in biological environments: A review. Biointerphases, 11(1), 018901. $10.1116 / 1.4934628$

Hedberg, Y., \& Wang, X., Hedberg, J., et al. (2013). Surface-protein interactions on different stainless steel grades: effects of protein adsorption, surface changes and metal release. Journal of Materials science: Materials in Medicine, 24(4):1015-1033. 10.1007/s10856-013-4859-8.

Isac, J., Chandrashekar, B. S., Mahendra, S., Mahesh, C. M., Shetty, B. M., \& Arun, A. V. (2015). Effects of clinical use and sterilization on surface topography and surface roughness of three commonly used types of orthodontic archwires. Indian Journal of Dental Research. 26(4):378-383. 
Jacobs, J. J., Skipor, A. K., Patterson, L. M., Hallab, N. J., Paprosky, W. G., Black, J., \& Galante, J. O. (1998). Metal release in patients who have had a primary total hip arthroplasty. A prospective, controlled, longitudinal study. The Journal of bone and joint surgery. American volume, 80(10), 1447-1458. 10.2106/00004623-199810000-00006

Jin-long, L.V., \& Hong-yun., L. (2012). Influence of tensile pre-strain and sensitization on passive films in AISI 304 austenitic stainless steel. Materials Chemistry and Physics, 135:973-978. 10.1016/j.matchemphys.2012.05.086.

Jorge, J. R., \& Barao, V. A., Delben, J. A., Assuncao, W. G. (2013). The role of implant/abutment system on torque maintenance of retention screws and vertical misfit of implant-supported crowns before and after mechanical cycling. The International Journal of Oral \& Maxillofacial Implants, 28(2):415-422. 10.11607/jomi.2727.

Kocijan, A., \& Merl, D. K., \& Jenko, M. (2011). Effect of Mo on interaction between $\alpha / \gamma$ phases of duplex stainless steel. Corrosion Science, 267:255-268. 10.1016/j.electacta.2018.02.082.

Luo, H., \& Su, H., Dong, C., Li. X. (2011). Characterization of passive film on 2205 duplex stainless steel in sodium thiosulphate solution. Applied Surface Science, 258(15):631-639. 10.1016/j.apsusc.2011.06.077.

Mathew, M. T., Barão, V. A., Yuan, J. C., Assunção, W. G., Sukotjo, C., \& Wimmer, M. A. (2012). What is the role of lipopolysaccharide on the tribocorrosive behavior of titanium? Journal of the mechanical behavior of biomedical materials, 8, 71-85. https://doi.org/10.1016/j.jmbbm.2011.11.004

McGuire, M. F. (2008). Stainless Steels for Design Engineers, United States of American.

Mishra, S. K., \& Chowdhary, R. (2014). Heat generated by dental implant drills during osteotomy-a review: heat generated by dental implant drills. Journal of Indian Prosthodontic Society, 14(2), 131-143. 10.1007/s13191-014-0350-6.

Newbury, D. E., \& Ritchie, N. W., (2013). Is Scanning Electron Microscopy/Energy Dispersive X-ray Spectrometry (SEM/EDS) Quantitative? Scanning, 35:141-168. 10.1002/sca.21041.

Oliveira, M. S., Borges, A. H., Mattos, F. Z., Semenoff, T. A., Segundo, A. S., Tonetto, M. R., Bandeca, M. C., \& Porto, A. N. (2014). Evaluation of different methods for removing oral biofilm in patients admitted to the intensive care unit. Journal of international oral health: JIOH, 6(3), 61-64.

Ribeiro, D. V., \& Abrantes, J. C. C. (2016). Application of electrochemical impedance spectroscopy (EIS) to monitor the corrosion of reinforced concrete: A new approach. Construction and Building Materials, 111:98-104. 10.1016/j.conbuildmat.2016.02.047.

Rutala, W. A., \& Weber, D. J. (2016). Disinfection and Sterilization in Health Care Facilities: An Overview and Current Issues. Infectious disease clinics of North America, 30(3), 609-637. https://doi.org/10.1016/j.idc.2016.04.00.

Roselino Ribeiro, A. L., Noriega, J. R., Dametto, F. R., \& Vaz, L. G. (2007). Compressive fatigue in titanium dental implants submitted to fluoride ions action. Journal of applied oral science: revista FOB, 15(4), 299-304. https://doi.org/10.1590/s1678-77572007000400011.

Sedriks, A.J. (1996). Corrosion of Stainless Steel, (2nd ed.), Wiley-Interscience.

Skale, S., \& Doleček, V., Slemnik. M. (2007). Substitution of the constant phase element by Warburg impedance for protective coatings. Corrosion Science, 49(3):1045-1055. 10.1016/j.corsci.2006.06.027.

Shemtov-Yona, K., \& Rittel, D. (2016). Fatigue failure of dental implants in simulated intraoral media. Journal of the mechanical behavior of biomedical materials, 62, 636-644. https://doi.org/10.1016/j.jmbbm.2016.05.028.

Sun, R.-j., \& Sun, Q.-q., Xie, Y.-h., Dong, P.-X., Chen, Q.-y., \& Chen, K.-h. (2016). Enhancing corrosion resistance of 7150 Al alloy using novel three-step aging process. Transactions of Nonferrous Metals Society of China, 26(5):1201-1210. 10.1016/S1003-6326(16)64192-4.

Tsaousis, K. T., \& Werner, L., Perez, J. P., et al. (2016). Comparison of different types of phacoemulsification tips. I. Quantitative analysis of elemental composition and tip surface microroughness. Journal of Cataract and Refractive Surgery, 42(9):1345-1352. 10.1016/j.jcrs.2016.02.052.

Valois, C. R., \& Silva, L. P., \& Azevedo, R. B. (2008). Multiple autoclave cycles affect the surface of rotary nickel-titanium files: an atomic force microscopy study. Journal of Endodontics, 34(7):859-62. 10.1016/j.joen.2008.02.028.

Virtanen, S., Milosev, I., Gomez-Barrena, E., Trebse, R., Salo, J., \& Konttinen, Y. T. (2008). Special modes of corrosion under physiological and simulated physiological conditions. Acta biomaterialia, 4(3), 468-476. https://doi.org/10.1016/j.actbio.2007.12.003.

Wilson, A. J., \& Nayak, S. (2016). Disinfection, sterilization and disposables. Anaesthesia \& Intensive Care Medicine, 17, 475-479. 10.1016/j.mpaic.2016.07.002.

Xin, X. Z., \& Chen, J., Xiang, N., Gong, Y., \& Wei, B. (2014). Surface characteristics and corrosion properties of selective laser melted Co-Cr dental alloy after porcelain firing. Dental Materials, 30(3):263-70. 10.1016/j.dental.2013.11.013. 